\title{
Skolebasert forebygging av røyking blant ungdom
}

\author{
Ola Jøsendal ${ }^{1}$, Leif Edvard Aarø ${ }^{2}$ og Ingunn Holden Bergh ${ }^{3}$ \\ ${ }^{1}$ Hemil-senteret, Universitetet i Bergen, Øisteinsgate 3, 5007 Bergen \\ ${ }^{2}$ Institutt for samfunnspsykologi, Universitetet i Bergen, Øisteinsgate 3, 5007 Bergen \\ ${ }^{3}$ Den Norske Kreftforening, Fridtjof Nansensvei 12, 0369 Oslo
}

\begin{abstract}
SAMMENDRAG
I første del av denne artikkelen gjennomgås en del utvalgte studier av skolebaserte tiltak mot røyking. Utviklingen har gått gjennom tre faser der den siste generasjonen er de omfattende tiltakene som baserer seg på en sosial påvirkningsmodell. Godt planlagte tiltak som er basert på denne modellen har vist seg å føre til at færre begynner å røyke. I artikkelens andre del presenteres et prosjekt som gjennomføres av Den Norske Kreftforening og som omfatter 4441 elever fra 195 klasser ved 99 ungdomsskoler. Valg av undervisningstema og pedagogiske tilnærminger er begrunnet $\mathrm{i}$ aktuelle sosialpsykologiske begreper og modeller og erfaringer fra tidligere forskning. Intervensjonen bygger et stykke på vei på en sosial påvirkningsmodell. Skolene er delt i fire grupper. Gruppe A er kontrollgruppe. Elevene i gruppe B gjennomgår et undervisningsprogram, foreldrene involveres og lærerne gjennomgår kurser i hvordan de skal gjennomføre intervensjonen. I gruppe $\mathrm{C}$ gjør en det samme som i gruppe B, men lærerne kurses ikke. I gruppe D gjør en det samme som i gruppe $\mathrm{B}$, men foreldrene involveres ikke. Underveis gjennomføres det blant annet spørreskjemaundersøkelser blant elevene for å studere endringer i røykevaner, hvilke grupper av elever en lykkes best i å nå, hvordan elevene reagerer på tiltakene og hva som kan forklare eventuelle positive virkninger av intervensjonene. Foreløpige analyser av resultatene etter et halvt års oppfølging tyder på at det er færrest som begynner å røyke i gruppe B, med andre ord at virkningene av tiltakene er best der lærerne kurses og foreldrene involveres.
\end{abstract}

\section{Jøsendal O, Aarø LE, Bergh IH. School-based prevention of smoking among youths. Nor J Epidemiol 1995; 5 (2): 161-170.}

\section{ENGLISH SUMMARY}

The first part of this article presents selected studies of school-based intervention programmes against smoking. Historically it can be distinguished between three phases in the development of such programmes. The last generation are the comprehensive social influence programmes. Carefully planned and designed interventions which have been based on this model have succeeded in hindering a substantial proportion of young people from starting smoking. The second part of this article presents a project which is administered by the The Cancer Society of Norway and which takes the social influences model as its point of departure. The project encompasses 4441 pupils in 195 classes at 99 secondary schools in Norway. The educational approach as well as the choice of topics covered are guided by relevant theory as well as findings from previous research. The schools have been allocated to four groups. Group A serves as control. The pupils in group B participate in the teaching programme, their parents are involved, and the teachers attend courses in school-based anti-smoking intervention. The pupils in group $\mathrm{C}$ are exposed to the same conditions as group $\mathrm{B}$, but the teachers are not offered the course. Pupils in group D are exposed to the same conditions as group $\mathrm{B}$, but their parents are not involved. Questionnaire surveys are carried out in order to examine changes in smoking habits, identify which groups we succeed in influencing, find out how the interventions are received and perceived by the pupils, and how to explain possible positive outcomes. Preliminary analyses of data collected six months after baseline indicate that the lowest recruitment of smokers is found in group B. Involving parents and arranging courses for teachers may prove to improve the effects of the programme. 


\section{INNLEDNING}

Både i Sverige (1) og Finland (2) er det i siste halvdel av 80-årene observert en økning i røyking blant ungdom $\mathrm{i}$ tenårene, og Statens tobakkskaderåds undersøkelser viste at det blant 15 år gamle jenter i Norge var litt mer røyking i 1990 enn i $1985(2,3)$. Den nedgangen i røyking som fant sted i befolkningen fra midten av 1970-tallet til et stykke ut i 80-årene, ser ut til å ha stoppet opp (3). Samtidig bekreftes de helseskadelige virkningene av røyking gjennom stadig nye undersøkelser (4). Det er derfor stort behov for å forsterke innsatsen mot røyking, ikke minst overfor ungdom.

Sussman og medarbeidere (5) har sammenliknet ulike former for tiltak for å forebygge røyking blant ungdom, og mener at de skolebaserte er mest effektive. Begrunnelsen er:

1. Dersom programmene gjennomføres i skoletiden, vil de aller fleste ungdommer vil bli eksponert. Dette i motsetning til intervensjoner på andre arenaer, der kun et avgrenset antall ungdommer er til stede samtidig.

2. Skoler er gjennom lover, forskrifter og regler pålagt å gi undervisning i helsespørsmål og å drive forebyggende helsearbeid. Det foreligger altså en form for indre insentiv til denne type aktivitet $i$ skolen.

3. Undervisningen foregår ansikt til ansikt, og det er derfor god anledning til toveis-kommunikasjon og å tilpasse pedagogikken til reaksjoner fra både klassen som helhet og enkeltelever.

Undersøkelser av forebyggende tiltak mot røyking blant ungdom har tradisjoner helt tilbake til 1950tallet. Amerikaneren Daniel Horn gjennomførte på den tiden felteksperimentelle studier der han sammenliknet virkningen av ulike undervisningsopplegg. Horn viste at enkelte pedagogiske framgangsmåter gav bedre resultat enn andre (6).

Siden Horn gjennomførte sine studier, har det kommet mange undersøkelser av liknende type. Noen evalueringer har ikke påvist noen vesentlig virkning av slike tiltak $(7,8)$, mens andre har gitt større grunn til optimisme. Det er utviklet nye begreper, modeller og teorier som gir oss holdepunkter for hva slags faktorer som er avgjørende for barn og unges røykevaner, og som gjør at vi kan forbedre intervensjonsmetodene $(9,4)$. Metastudier har gitt oss et klarere bilde av hvilke typer av intervensjoner som gir best effekt $(10,11)$.

Faktorer som predikerer røyking hos unge har blitt studert inngående. Røykerne er for eksempel gjennomsnittlig noe mer ukonvensjonelle enn sine jevnaldrende (12), mer stimulussøkende (4), skoletrøtte (13), har flere røykere i nærmiljøet (14), og er oftere sosialt isolerte (15). I tillegg kan vi nevne variasjoner etter bosted og bostedsmønster (14), sosioøkonomisk status og utdanningsnivå hos foresatte (4). Disse funnene forteller ikke bare om faktorer som påvirker røykingen, men sier også mye om hvilke undergrupper vi i særlig grad bør forsøke å nå.

Basert på tidligere forskning på dette feltet har Den Norske Kreftforening (DNK) utviklet og implementert en intervensjon som er kalt "VÆR røykFRI". I denne artikkelen skal vi presentere utvalgte biter av forskningen om skolebaserte tiltak mot røyking og vi skal presentere noen av de første resultatene som foreligger fra evalueringen av Den Norske Kreftforenings tiltak for en røykfri skole.

\section{SKOLEBASERTE INTERVENSJONER I NORGE}

\section{Statens tobakkskaderåd 1978-79}

På slutten av 1970-tallet utviklet Statens tobakkskaderåd en skolebasert intervensjon for å redusere røyking blant barn i 6.-9. klasse i grunnskolen. Programmet ble prøvd ut $\mathrm{i}$ to omfattende felteksperimentelle undersøkelser.

Den første intervensjonen ble gjennomført i Valdres i 1978. Intervensjonen var basert på følgende hovedprinsipper, der samtlige var utledet fra sentral sosialpsykologisk forskning om påvirkning:

- sterkere fokusering på korttidseffekter enn langtidseffekter av røyking.

- forsøk på å sette røyking i sammenheng med aktuell debatt om forurensning, miljøvern og forvaltning av naturressursene.

- mobilisering av sosial støtte fra foreldrene.

- aktivisering av elevene ved å skrive stil om emnet.

Skoler i Valdres ble valgt ut til å være med i forsøket. De ble delt inn i fire grupper, og i hver gruppe av skoler ble undervisningen gjennomført på litt forskjellig måte. Det skriftlige undervisningsmateriellet som var utarbeidet på forhånd, ble benyttet $i$ alle fire gruppene og gjennomgått i løpet av 1-2 skoletimer. I gruppe 1 begrenset en intervensjonen til dette. I gruppe 2 lot en i tillegg elevene skrive en norsk stil der oppgaven var formulert slik at de ble nødt til å argumentere ensidig mot røyking. I gruppe 3 skrev elevene ikke stil, men foreldrene ble involvert gjennom en folder som ble sendt med elevene hjem. I gruppe 4 kombinerte en skriving av skolestil med involvering av foreldrene. Nedgangen i sigarettforbruket ble $6 \%, 13 \%, 15 \%$ og $21 \%$ henholdsvis i gruppene $1,2,3$ og 4 . Dette resultatet ble målt mindre enn en uke etter avsluttet kampanje.

En forbedret versjon av det samme tiltaket ble gjennomført ved skoler i Hamar, Lillehammer og Ringsaker i 1979. I dette forsøket opererte en bare med intervensjonsgruppe og kontrollgruppe. En oppfølging ett år etterpå viste at det var $29 \%$ røykere i intervensjonsgruppen mot $37 \%$ røykere i kontrollgruppen. I utgangspunktet var det mindre enn ett prosentpoengs forskjell mellom gruppene (16). 


\section{"Kjenn din kropp" 1979-81}

Ved seks barne- og ungdomsskoler skoler i Oslo ble det årene 1979 til 1981 gjennomført tiltak for å redusere risikoen for hjerte-karsykdom. Tre av skolene ble valgt ut til intervensjonsskoler, mens tre andre var kontrollskoler. Denne studien var en del av et større internasjonalt prosjekt om helsefremmende og forebyggende arbeid blant unge (17). Blant annet forsøkte en gjennom et ti timers undervisningsprogram i ungdomsskolen å redusere røykingen blant elevene. Timene ble fordelt over to skoleår.

Hovedprinsippene for intervensjonen var:

- Undervisning i de sosiale, politiske og helsemessige aspektene ved røyking

- Bruk av eldre elever som "lærere" i klasserommet

- Trening i sosiale ferdigheter for å motstå røykepress

- Presentasjon av personlige rollemodeller

- Åpne avtaler om å forbli røykfri (offentlige i klassen)

Vi skal merke oss at de spesifikke elementene som tok for seg røyking, var en del av en større intervensjon som også omhandlet kosthold og fysisk aktivitet.

I løpet av de to første årene etter intervensjonen var det, når en sammenliknet med kontrollgruppen, $40 \%$ færre som begynte å røyke i intervensjonsgruppen (18). Etter ti år var det imidlertid ingen statistisk sikker forskjell i røyking mellom intervensjonsgruppen og kontrollgruppen (19). Dersom resultatene analyseres for menn og kvinner separat, er det imidlertid signifikant færre røykere blant menn i intervensjonsgruppen enn blant menn i kontrollgruppen etter ti år (25\% færre).

\section{SKOLEBASERTE INTERVENSJONER MOT RØYKING I USA}

I perioden fra 1980 til 1994 har det ikke vært gjennomført noen større evalueringsundersøkelser av tiltak mot røyking blant norske skoleelever. Imidlertid har det $\mathrm{i}$ den samme tidsperioden $\mathrm{i}$ andre land vært gjennomført en lang rekke tiltak, der noen av dem har vist god effekt på ungdoms røykeatferd. USA har vært et foregangsland i dette arbeidet. I rapporten "Preventing Tobacco Use Among Young People" (9) er utviklingen av de skolebaserte forebyggingsprogrammene i USA delt inn i faser:

\section{Fase 1: Kunnskapsbaserte tiltak}

På 1960- og 70-tallet mente man at folk flest visste for lite om tobakkens skadelige virkninger, og at dette var en viktig årsak til at så mange røykte. Kampanjer og intervensjoner som tok sikte på å gi økte kunnskaper om røyking og helse ble gjennomført.
Med unntak av Horns (6) undersøkelse fra slutten av 1950-tallet, fant man at de kunnskapsbaserte tiltakene hadde liten eller ingen effekt på røykingen.

\section{Fase 2: Affektive tiltak}

Utover på 1970-tallet ble det utviklet programmer som mer tok hensyn til emosjonelle eller affektive prosesser. Intervensjonene tok sikte på å øke elevenes selvfølelse og bygge opp en verdiorientering som gikk i retning røykfrihet. Heller ikke disse programmene gav særlig gode effekter på atferd.

\section{Fase 3: Mer omfattende intervensjonsprogrammer med vekt på sosial påvirkning}

I løpet av 70-årene ble det gjennomført en rekke studier som viste at sosiale påvirkninger spiller en helt avgjørende rolle ved røykestart (14). De forebyggende tiltakene hadde $\mathrm{i}$ stor grad undervurdert disse faktorenes betydning. I de mer omfattende intervensjonene som er blitt gjennomført i 1980- og 90-årene, har en lagt større vekt på slike elementer som trening $i$ å motstå sosialt press og sosial støtte til å ikke røyke. Gjennom en kort beskrivelse av to slike program skal vi se nærmere på innholdet $\mathrm{i}$ intervensjoner $\mathrm{i}$ fase 3 . Effekten av flere slike intervensjoner har vært god.

\section{"Life skills training"}

Gilbert Botvin og medarbeidere har utviklet et intervensjonsprogram kalt "Life skills training" (LST). Programmet er blitt prøvd ut $\mathrm{i}$ en serie felteksperimentelle studier som holder god kvalitet rent vitenskapelig (20). Vi skal gå nærmere inn på ett av disse forsøkene.

Botvin og medarbeidere (21) gjennomførte et felteksperiment i 10 forsteder til New York. Elevene gikk i 7. klasse, og var hovedsakelig hvite og fra middelklassen. Undervisningsprogrammet omfattet ikke bare undervisning om de mer langsiktige virkningene av røykingen, men også virkningene på kort sikt. Videre la en vekt på trening av sosiale ferdigheter, inkludert teknikker for å motstå direkte sosialt press. En lot eldre elever fungere som "lærere" overfor yngre elever. For å holde emnet aktuelt og opprettholde elevenes engasjement, fikk de oppgaver å arbeide med også utenom ordinær skoletid. Volumet på undervisningen var 20 skoletimer på ett skoleår.

Evalueringen viste at programmet hadde god effekt. Det var etter at programmet var avsluttet signifikant færre røykere i intervensjonsgruppen enn i kontrollgruppen. Imidlertid hadde antallet røykere økt $\mathrm{i}$ begge grupper, men langt mindre i intervensjonsgruppen. I en oppsummering av sine mange forsøk sier Dusenbury \& Botvin (20) at programmene har lyktes i å redusere rekrutteringen av røykere i de aktuelle aldersgruppene med mellom 40 og 75 prosent, og de har registrert effekter av inntil 2 års varighet. 
I en annen av sine publikasjoner sier Botvin \& Dusenbury (22) at de tradisjonelle metodene som formidling av fakta om røykingens helseskadelige konsekvenser og fryktvekkende informasjon med moralske overtoner ikke fungerer. Det som kjennetegner de mer effektive tiltakene som etterhvert er blitt utviklet, er at ungdom trenes systematisk i å motstå sosialt press, særlig slikt press som kommer fra media og fra jevnaldrende. Det som skiller LST fra andre virkningsfulle tiltak, er at en arbeider med å påvirke de mellommenneskelige prosessene som ofte motiverer ungdom til å begynne å røyke.

\section{Minnesota Heart Health Program 1983-89}

Gjennom "Minnesota Heart Health Program" (MHHP) gjorde man et forsøk på å redusere forekomsten av hjerte-karsykdommer i tre store lokalsamfunn i USA (23). En del av intervensjonen foregikk i skolene, gjennom et opplegg som strakte seg over fem år. Elever valgt av sine klassekamerater ble brukt som "lærere" i klassen. Elevene fikk trening i å vurdere egne atferdsmønstre samt trening $\mathrm{i}$ å vurdere det sosiale miljøet, og forsøke å påvirke dette. Elevene fikk også trening i å motstå sosialt press samt trening $\mathrm{i}$ autonomi. I tillegg ble elevene aktivisert gjennom arbeid med skoleavis, utsending av postkort, og rollespill. Staben som hadde ansvaret for gjennomføringen av intervensjonen, brukte om lag ett år på å forhandle med lokale politikere og administrasjonen om rammebetingelsene for prosjektet. Volumet var om lag 30 ordinære skoletimer, fordelt over fem år.

Ved slutten av intervensjonen var det $10 \%$ av intervensjonsgruppen som røykte, mens det var $21 \%$ av kontrollgruppen som røykte. I 1989, to år etter siste del av intervensjonen, var det fremdeles $40 \%$ færre røykere $\mathrm{i}$ intervensjonsgruppen enn i kontrollgruppen. Det vil si at man gjennom prosjektet utviklet store forskjeller i forbruket av røyk, og at disse forskjellene ble opprettholdt over lang tid (24).

På bakgrunn av erfaringene fra tidligere norske studier og de amerikanske studiene som er referert ovenfor, satte Den Norske Kreftforening i 1994 arbeidet med å utvikle et norsk intervensjonsprogram som er kalt "VÆR røykFRI". Dette skal i det følgende presenteres nærmere, og vi skal se på noen av de første resultatene som foreligger fra evalueringen.

\section{"V FR røykFRI" - ET PROSJEKT I REGI AV DEN NORSKE KREFTFORENING, 1994-1996}

Den Norske Kreftforening har satt opp tre hovedmålsettinger med prosjektet:

1. Å opprettholde røykfrihet i elevgruppene

2. Å identifisere en eller flere faktorer som opprettholder røykfrihet i elevgruppene

3. Å utvikle tiltak og metoder i anti-tobakksarbeidet som kan bidra til å holde hele alderskullet røykfritt
Valget av intervensjonsmetoder er i alt vesentlig sammenfallende med retningslinjene som blant annet er gitt i rapporten "Preventing Tobacco Use Among Young People" (9) og i boken "Developing schoolbased tobacco use prevention and cessation programs" (5). Det er allikevel viktig å presisere at programmet har fått en meget selvstendig og særpreget profil. Programmets kjernebudskap og bærende idé er "å utdype og konkretisere for identitetssøkende ungdom hva det er å være et fritt og selvstendig menneske. Det handler om å bevisstgjøre dem om hva de selv ønsker, og samtidig inspirere dem til å utvikle sine egne lystbetonte handlingsalternativer i situasjoner der røyk kan være et aktuelt valg." (Sitat fra innledning til leksjonsperm som ble utdelt til lærerne.)

Elevene har gått igjennom 8 leksjoner i 7. klasse. De skal ha 5 leksjoner i 8. klasse og omtrent tilsvarende for 9. klasse. Leksjonsinnholdet i de ulike timene kan fungere som oversikt over emner DNK har valgt å legge vekt på. Nedenfor presenteres hvilke emner som har blitt drøftet i hver time. Alle leksjonene skal ha elementer av undervisning som ikke er kateterforelesninger, f.eks. gruppearbeid, videoframvising, rollespill etc. I leksjonene er det lagt vekt på å aktivisere alle elevene. Det er lagt opp til hjemmearbeid mellom de aller fleste leksjonene.

\section{Emner i leksjonene i 7. klasse:}

1. Om utbredelsen av røyking, om grunner til å røyke, om å skjelne mellom hensikt og handling, om alternativer til å røyke, om å være fri.

2. Om hvorfor ungdom røyker, om lystbetonte alternativer til røyking.

3. Om røykepress, om motiver for å utøve røykepress, trening i å si nei til røyk.

4. Om ulike metoder for å oppfylle et ønske, om konstruktiv kritikk, om omsorg for hverandre.

5. Om påvirkning og manipulering, om reklame, om tobakksindustri og reklame, om snikreklame, om røyking i kulturelle uttrykksformer.

6. Mer om snikreklame, rollespill der elevene intervjuer en tobakksfabrikant, utvikle motstrategier i forhold til snikreklame eller skjult påvirkning.

7. Om korttidskonsekvenser av røyking, om avhengighet, elevene lager kollasj.

8. Om å være fri og selvstendig, at røyk er frihetsberøvende, om fordelene ved å være røykfri.

Med tanke på å få til et opplegg som gir redusert røyking blant elevene er det nødvendig å få til en god kombinasjon av innhold i de ulike leksjonene og anvendelse av bestemte helsepedagogiske prinsipper.

Innledningsvis beskrev vi innhold og opplegg i ulike undervisningsprogram, og vi vet fra evalueringsundersøkelsene at disse tiltakene hadde atferdsmessige effekter, med andre ord at de bidro til redusert røyking. For å si noe om hvorfor ulike tiltak virker, må vi gå til den teoretiske bakgrunnen for slike 
intervensjoner. De fleste baserer seg på sosialpsykologisk teori og forskning.

\section{Noen sentrale begreper og pedagogiske prinsipper}

"VÆR røykFRI"- intervensjonen fokuserer sterkt på individets muligheter til å velge. Økt tiltro til at en selv har muligheter til å påvirke sin helse og sitt velvære gjennom fornuftig valg av livsstil handler blant annet om å øke graden av det som med sosialpsykologiske ord kalles indre helsemessig kontrollplassering. Innen sosialpsykologien utviklet en allerede på 50-tallet en teori om kontrollplassering $(25,26)$. Denne er senere utviklet til et begrep om helsemessig kontrollplassering (27). Økt tiltro til at en selv kan gjøre noe for å ta vare på helsen vil representere en påvirkning $\mathrm{i}$ retnng av at individet faktisk tar et slikt ansvar. Det er interessant å registrere at en bærende idé innen health-promotion ideologien nettopp er tanken om at en skal styrke den enkelte og fellesskapets kontroll med faktorer som virker inn på helsen (28).

Budskapet om å være fri fra røykingen har en annen viktig side. En av de hindringene en ofte støter på når en forsøker å påvirke helserelaterte atferdsmønstre gjennom opplysningstiltak, er den enkeltes naturlige ønske om selv å bestemme og ikke bli fortalt av andre hva en skal gjøre. Sosialpsykologen Brehm (29) har utviklet et eget begrep, "reaktans", om tendensen til å reagere negativt når ens handlingsalternativer blir begrenset av andre. Ved å legge vekt på at det nettopp er den enkelte selv som må velge, og at det å ikke røyke er en slags frihet, reduserer en risikoen for å utløse reaktans.

Mens en tidligere antok at kunnskaper om de helsemessige konsekvensene av atferd hadde mye å si for denne atferden, opererer en i dag med begrepet "resultatforventninger" (30,31). Resultatforventninger er definert som de forestillinger en har om konsekvensene av en atferd. Dette handler ikke bare om de helsemessige konsekvensene, men også om konsekvenser sosialt, økonomisk og med tanke på livskvalitet. For en ungdom som velger å ikke røyke kan en konsekvens være tap av popularitet $\mathrm{i}$ en gjeng av røykere. Mulige gevinster kan være bedre prestasjoner i idrett eller mer penger til andre ting. En vanlig antakelse innen sosial læringsteori er at kortsiktige konsekvenser styrer atferd sterkere enn langsiktige. Dette var ett av prinsippene som ble lagt til grunn for intervensjonen i "VÆR røykFRI". Derfor har også elevene som er involvert i prosjektet fått en god innføring i de umiddelbare følgene av røyking. I tillegg til de fysiske følgene har det også blitt fokusert på de økonomiske og sosiale følgene.

Bandura har også utviklet begrepet "mestringsforventninger" som handler om individers forventinger til å mestre ulike former for atferd. Ungdommer som har høy mestringsforventing i forhold til det å kunne si "nei takk" til et tilbud om røyk, eller en stor tro på å kunne mestre fristelsen til å prøve sigaretter, har mindre sannsynlighet for å begynne å røyke. Intervensjonen "VÆR røykFRI" har flere innslag der elevene skal leve seg inn i aktuelle situasjoner, og øve seg på å mestre røykepress eller fristelse til å røyke.

Undersøkelser har vist at en kan påvirke individer sterkere gjennom å engasjere og aktivisere enn ved å la dem være passive (32). Dette er også vist i forbindelse med antirøyketiltak blant skolebarn (16). Strategien kalles ofte for indusert føyelighet (induced compliance) (33). Mot slutten av 7. klasseintervensjonen fikk elevene i oppgave å lage sitt eget uttrykk for fordelene eller gleden ved å være røykfri. Elevene kunne selv velge en form eller kunstnerisk innslag som framhevet røykfrihet. Slik ble alle elevene invitert til å fremme et røykfritt standpunkt. De valgte aktiviteter som å lage caps'er, T-skjorter, dikt, videofilmer, drakter, plakater. Jo større grad av frivillighet de opplever under arbeidet med disse aktivitetene, desto større vil sannsynligvis effekten bli.

En sentral konklusjon fra forskningen om røykevaner blant ungdom er at sosiale påvirkninger spiller en helt avgjørende rolle for hvem som begynner å røyke og hvem som lar være (14). Andre undersøkelser har vist at dersom en greier å mobilisere sosial støtte for det å slutte å røyke, blir det mindre røyking blant ungdom (16). I "VÆER røykFRI" har en derfor lagt opp til å se på virkningen av å involvere foreldrene i tiltaket og forsøke å mobilisere disse til støtte for sine egne barn.

Dette var eksempler på begreper og påvirkningsprinsipper som er kommet til anvendelse i intervensjonen. Evalueringsundersøkelser vil bare i noen grad kunne belyse hvordan hvert enkelt element bidrar til å påvirke atferd. En kan vise hva som er den samlede effekten av tiltak som baserer seg på tidligere forskning. En kan også gjennom å operere med flere intervensjonsgrupper se på effekten av bestemte faktorer. Ved å måle noen av de faktorene en tror er virksomme (f.eks. grad av elevinvolvering), kan en også se om disse bidrar til å predikere atferd.

\section{METODE}

Ved hjelp av spørreskjema blir elevene fulgt gjennom hele ungdomsskolen. Utvalget av skoler er trukket sekvensielt fra en geografisk ordnet liste over alle ungdomsskoler i landet. Alle elevene på det aktuelle klassetrinnet (7.klasse i skoleåret 1994/95) ved de utvalgte skolene er med i utvalget, totalt 4441 elever. Fra $95 \%$ av elevene/foreldrene foreligger det samtykke til å delta i spørreundersøkelsene.

Evalueringen blir gjennomført som et felteksperiment med tre intervensjonsgrupper og en kontrollgruppe. Skolene er delt inn i fire grupper. Gruppe A er kontrollgruppe, gruppe $\mathrm{B}$ får undervisningsprogram, kurs av lærere og involvering av foresatte. 
Gruppe C er lik gruppe B, men lærerne får ikke kurs. I gruppe $\mathrm{D}$ er opplegget også likt gruppe $\mathrm{B}$, men her blir ikke foresatte involvert som en del av prosjektet.

Det ble gjennomført spørreskjemaundersøkelser blant elevene før intervensjonen startet og etter $1 / 2$ år. I tillegg til spørsmål om røykevaner og enkle demografiske opplysninger har en ved forundersøkelsen blant annet stilt spørsmål om stimulussøking, antisosial atferd, signifikante andres røykevaner og fysiske tegn på pubertetsutvikling. Ved hver oppfølgende undersøkelse blir elevenes røykevaner på nytt kartlagt, og det blir stilt spørsmål om hvordan elevene vurderer de ulike sidene av undervisningsprogrammet. Det blir samtidig innhentet opplysninger om selve gjennomføringen i klassene og lærernes vurdering av de ulike delene av undervisningsopplegget. I tillegg gjennomføres det også en kvalitativ undersøkelse av hvordan undervisningen fungerer $\mathrm{i}$ enkelte skoleklasser.

\section{Intervensjon}

Undervisningen av elevene begynte i oktober/november 1994. Undervisning og spørreundersøkelser er satt opp slik som vist i Figur 1.

Mellom de fleste undervisningstimene er det lagt opp til noe hjemmearbeid. Samtaler med lærerne har vist at der timene fenger elevene, blir det brukt flere timer enn det som står i skjemaet ovenfor. Hver lærer fyller ut et kort evalueringsskjema etter hver undervisningstime.

\section{RESULTATER}

Forundersøkelsen ble gjennomført i november 1994. 4215 elever ( $95 \%$ ) besvarte et forholdsvis omfattende spørreskjema. Skjemaet ble fylt ut i løpet av en skoletime. Første etterundersøkelse ble besvart av 3 846 elever (91\% av dem som besvarte forundersøkelsen). Frafallet skyldtes i hovedsak at 2 skoler trakk seg og at enkeltlærere ikke hadde gjennomført spørreundersøkelsen i sin klasse på grunn av tidspress eller sykemelding. En av de to skolene som trakk seg begrunnet det med at elevene etter lærerens oppfatning ikke fattet interesse for prosjektet.

Det var ingen nevneverdig forskjell i røykevaner mellom gutter og jenter i forundersøkelsen, og heller ikke i første etterundersøkelse. Resultatene viser derimot i etterundersøkelsen en tydelig forskjell i røykevaner mellom de ulike gruppene av skoler som inngår i evalueringen.

Tabell 1 viser prosent røykere i de forskjellige gruppene i november 1994 og i mai 1995. Det går fram av tabellen at det i utgangspunktet var en viss forskjell i røykevaner mellom de fire gruppene $i$ eksperimentet. Forskjellen er imidlertid ikke statistisk signifikant. Tabellen viser også at det har vært en særlig gunstig utvikling i den ene av intervensjonsgruppene. Under den intervensjonsbetingelsen som både omfatter kursing av lærere og involvering av foreldre (gruppe B), er det totalt 7,6 \% som røyker (daglig, ukentlig eller sjeldnere) ved etterundersøkelsen, mot 11,9\% i kontrollgruppen (gruppe A).

\section{Figur 1}

\section{DESIGN FOR FELTEKSPERIMENT, "VAR røykFRI"}

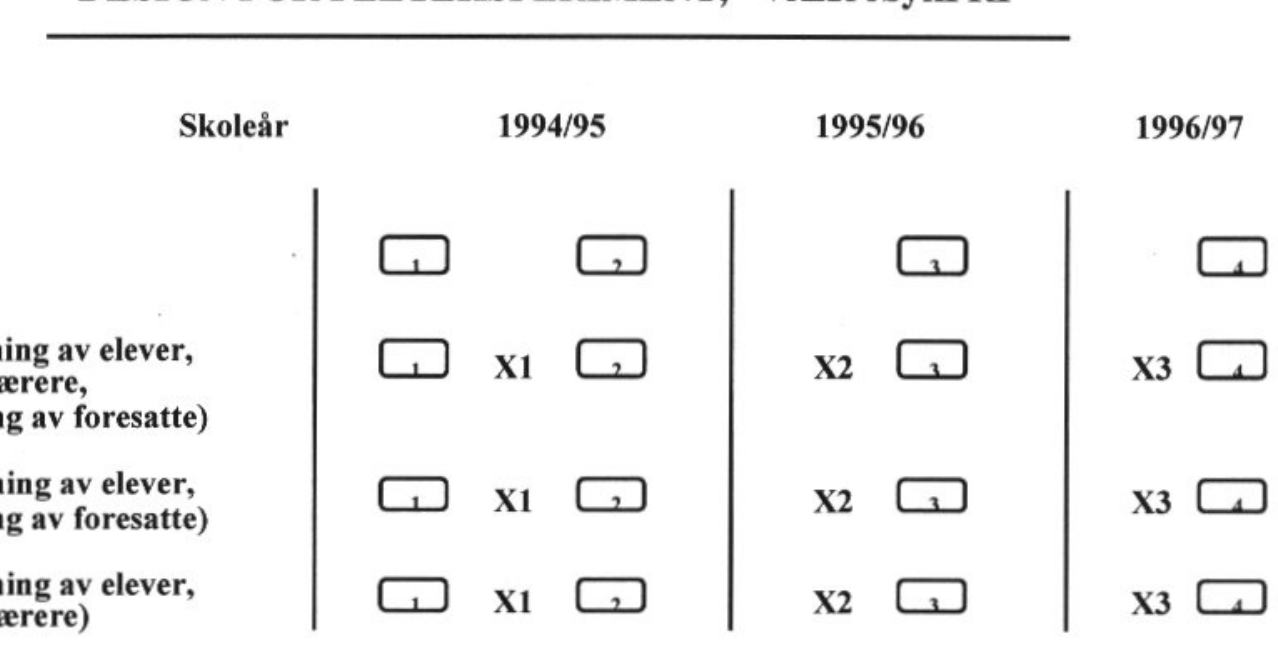

Skolegruppe

Gruppe A (kontroll)

Gruppe B (Undervisning av elever,
kurs for lærere,
involvering av foresatte)

Gruppe $C$ (Undervisning av elever, involvering av foresatte)

\section{Gruppe D (Undervisning av elever,} kurs for larere)
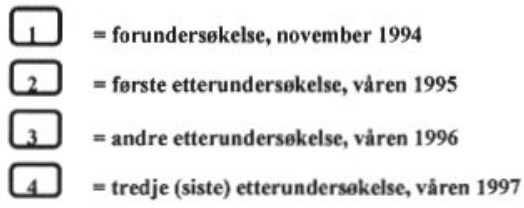

X1 = intervensjon i 7. klasse

X2 = intervensjon i 8. klasse

X3 = intervensjon i 9. klasse 
De to andre gruppene havnet $\mathrm{i}$ en mellomposisjon. Dersom en ser på endring fra forundersøkelsen til etterundersøkelsen, er den minst gunstig i kontrollgruppen $(5,7$ prosentpoengs økning $\mathrm{i}$ andel som røyker mot 1,7 prosentpoeng i gruppe B). På nytt havner gruppe $\mathrm{C}$ og $\mathrm{D}$ i en mellomposisjon.

Tabell 2 viser røykevaner ved etterundersøkelsen som en funksjon av kjønn, røyking ved forundersøkelsen og eksperimentbetingelse i en multippel logistisk regresjon. Røyking er her definert som det å røyke daglig, ukentlig eller sjeldnere. Siden røyking er en lavprevalent atferd på dette alderstrinnet, og siden eksperimentering med røyking er forløperen til vanerøyking, er det rimelig å analysere alle grader av røyking mot ikke-røyking. Variabelen er med andre ord dikotomisert slik at røykere får tallverdien 1 mens ikke-røykere får tallverdien 0 .

Trass $\mathrm{i}$ at vi her ikke lenger benytter en additiv modell, men en multiplikativ, blir bildet nesten det samme. Når odds ratio for røyking i kontrollgruppen

Tabell 1. Røykevaner ved forundersøkelsen og ved etterundersøkelsen etter eksperimentgruppe ${ }^{1}$ (Elever som er identifisert, og som har besvart spørsmålet om røyking på begge tidspunkt)

Forundersøkelsen (november 1994) ～Etterundersøkelsen (mai 1995)

Røyker ... $\quad$ Røyker ...

Daglig Ukentlig Sjelden Ikke Totalt Daglig Ukentlig Sjelden Ikke Totalt

$\% \quad \% \quad \% \quad \% \quad \%$

$\% \quad \% \quad \% \quad \% \quad \%$

\begin{tabular}{lllllllllll}
\hline Gruppe A & 1,8 & 0,8 & 3,7 & 93,8 & 100,1 & 4,0 & 2,3 & 5,5 & 88,1 & 99,9
\end{tabular}

$(\mathrm{n}=793)$

\begin{tabular}{lcccccccccc}
$\begin{array}{l}\text { Gruppe B } \\
(\mathrm{n}=833)\end{array}$ & 0,7 & 1,4 & 3,7 & 94,1 & 100,1 & 1,9 & 1,6 & 4,1 & 92,4 & 100,0 \\
$\begin{array}{l}\text { Gruppe C } \\
(\mathrm{n}=522)\end{array}$ & 1,5 & 1,3 & 3,3 & 93,9 & 100,0 & 3,6 & 1,0 & 4,2 & 91,2 & 100,0 \\
$\begin{array}{l}\text { Gruppe D } \\
(\mathrm{n}=674)\end{array}$ & 2,8 & 1,5 & 4,5 & 91,2 & 100,0 & 4,6 & 2,4 & 6,8 & 86,2 & 100,0 \\
\hline
\end{tabular}

$\mathrm{n}=2822$

${ }^{1}$ Tabellen omfatter kun personer som har deltatt ved begge undersøkelsene. I en del tilfeller har det grunnet manglende personidentifikasjon ikke vært mulig å koble svarene. Det vil bli arbeidet med å forbedre denne koblingen. Resultatene som presenteres i tabellene må derfor betraktes som foreløpige.

Tabell 2. Røykevaner ved oppfølgingsundersøkelsen etter kjønn, røykevaner ved forundersøkelsen og eksperimentgruppe (multippel logistisk regresjon, $n=2822$ ).

\begin{tabular}{|c|c|c|c|c|c|}
\hline & $\begin{array}{l}\text { Justert } \\
\text { odds ratio }\end{array}$ & Wald & $\begin{array}{l}\text { frihets- } \\
\text { grader }\end{array}$ & $\begin{array}{c}\mathrm{p}- \\
\text { verdi }\end{array}$ & $\begin{array}{c}95 \% \\
\text { konfidensintervall }\end{array}$ \\
\hline \multicolumn{6}{|l|}{ Kionn: } \\
\hline Gutt & 1,00 & & & & \\
\hline Jente & 0,89 & 0,62 & 1 & - & $0,68-1,19$ \\
\hline \multicolumn{6}{|l|}{ Roykevaner ved forundersokelsen: } \\
\hline Røyker ikke & 1,00 & & & & \\
\hline Daglig, ukentlig eller sjeldnere & 26,34 & 53,32 & 1 & 0,001 & $18,73-37,04$ \\
\hline \multicolumn{6}{|l|}{ Eksponeringsgruppe: } \\
\hline A (kontroll) & 1,00 & & & & \\
\hline $\mathrm{B}$ & 0,55 & 9,78 & 1 & 0,01 & $0,37-0,80$ \\
\hline $\mathrm{C}$ & 0,66 & 3,82 & 1 & - & $0,43-1,00$ \\
\hline $\mathrm{D}$ & 1,06 & 0,09 & 1 & - & $0,74-1,50$ \\
\hline
\end{tabular}


er satt til 1,00 , blir justert odds ratio under den maksimale intervensjonen (gruppe B) $0,55(\mathrm{p}<0,01)$. I gruppe $\mathrm{C}$, der lærerne ikke kurses, men foreldrene involveres, er justert odds ratio $0,66(p=0,06)$. I gruppe D, der lærerne kurses, men foreldrene ikke involveres, er justert odds ratio faktisk noe høyere enn i kontrollgruppen (ikke signifikant).

\section{DISKUSJON}

Resultatene er basert på analyser som er gjort på over 2800 individer. Selv små forskjeller mellom gruppene vil derfor kunne gi statistisk signifikans. Siden vi her er ute etter å se på forskjeller i rekruttering til røyking over en kort tidsperiode, og siden røyking i de aktuelle aldergruppene er en lavprevalent atferd, er det avgjørende å ha et såpass stort utvalg.

Frafallet i de ulike gruppene er noe forskjellig. I gruppe A er det faktisk flere elever som har svart $\mathrm{i}$ mai 1995 enn i november 1994. I gruppe B er det et frafall på rundt $5 \%$ av utvalget. Hovedtyngden av frafall er kommet i gruppe $\mathrm{C}$ der $23 \%$ av elevene har falt ut. Det er meget sannsynlig at dette har sammenheng med at lærerne i denne gruppen ikke får delta på kurs. Imidlertid synes effekten av programmet å være større i denne gruppen enn i gruppe $\mathrm{D}$, der man ikke har involvert de foresatte. Frafallet i gruppe D er på om lag $12 \%$.

Det er også viktig å merke seg at det ved forundersøkelsen var flest røykere i gruppe D. Fergusson og Horwood (34) har vist at barn raskere og raskere går fra eksperimenterende røyker til vanerøyker med økende alder, og at sannsynligheten for å gå fra eksperimenterende røyker til ikke-røyker synker med økende alder. Det behøver ikke bare være alder som slår ut slik. Siden det her er snakk om grupper der det er få som røyker, kan det like gjerne være at jo flere som røyker, desto flere rekrutteres til røyking. Selv om forskjellene i antallet røykere mellom de ulike intervensjonsgruppene ved baseline i denne studien ikke var statistisk signifikante, kan likevel slike forskjeller ha innvirkning på utviklingen av røykevaner. I lys av teorien om "Diffusion of innovations" (35) kan vi kanskje si at økningen i antallet røykere i gruppe D skyldes en uforholdsmessig stor gruppe innovatører (røykere). Rogers hevder at vi må ha et visst minste antall personer som går foran før et større antall følger opp.

Frafallet synes ikke å utgjøre noen alvorlig feilkilde. Vi har sammenlignet de elevene som er falt ut av studien med øvrige elever på en lang rekke sentrale variabler fra forundersøkelsen, og ikke funnet noen signifikante forskjeller. I tabellene har vi dessuten begrenset analysene til identifiserbare individer som har svart ved begge undersøkelsene. Vi har foretatt tilsvarende beregninger på bakgrunn av alle som har svart ved forundersøkelsen og alle som har svart ved oppfølgingsundersøkelsen. Forskjellene i endring mellom gruppene blir bare tydeligere av at alle observasjoner tas med.

Resultatene så langt er lovende, og tyder på at vi også i 1990-årene klarer å redusere rekrutteringen til røyking med godt planlagte tiltak. Dersom det viser seg at forskjellen mellom minst en av intervensjonsgruppene og kontrollgruppen i rekruttering til røyking fortsetter å øke over tid, kan det være grunn til å sette i gang tilsvarende intervensjoner $\mathrm{i}$ et større antall skoler.

Så langt ser det ut til at de intervensjonene som involverer foreldrene slår best ut. Dette bekrefter funn fra en tidligere norsk undersøkelse (16), som viste at effekten av et skolebasert tiltak mot røyking ble bedre når foreldrene ble trukket med. Mobilisering av sosial støtte til røykfrihet synes med andre ord fremdeles å være en virksom faktor.

Det er for tidlig å si noe endelig om effekten av å kurse lærerne. Når det å trekke med foreldrene kombineres med kursing av lærerne, reduseres røykingen mer enn når en bare trekker med foreldrene. Denne forskjellen er imidlertid ikke statistisk sikker. Før en bestemmer seg for hvilken strategi som skal følges når dette tiltaket skal settes ut $\mathrm{i}$ livet nasjonalt, må det imidlertid avklares om lærerkurser er en nødvendig $\mathrm{del}$, og om en såpass dyr investering som lærerkursene representerer er en kostnadseffektiv framgangsmåte.

Et hovedpoeng med det foreliggende prosjektet er at vi ikke bare skal undersøke om intervensjonen gir redusert rekruttering til røyking. Vi skal se nærmere på faktorer som kan holde ungdom røykfri, og vurdere programmets effekt i ulike undergrupper av ungdommene. Dersom intervensjonen passer best for de skoleflinke, dem med lav poengsum på stimulussøking eller dem som oppnår lav poengsum på antisosial atferd, er det ikke tilfredsstillende. Men det kan synes som om Den Norske Kreftforening har lyktes i å utvikle en intervensjon som spesielt når de gruppene som er vanskelige å få i tale gjennom skolebaserte intervensjoner (upubliserte resultater). Dette vil vi komme tilbake til i nye publikasjoner. Vi vil også se nærmere på hvordan elever og lærere opplever de ulike delene av intervensjonen med tanke på å kunne gjøre forbedringer.

I de statistiske analysene som er gjort her, har vi basert oss på ordinær slutnings-statistikk. Det er ikke tatt hensyn til at det foreligger klyngeutvalg. Konsekvensen av dette er sannsynligvis noe for snevre konfidensintervaller og at vi for lett oppnår signifikans. I fortsettelsen vil dette bli tatt hensyn til ved bruk av en design-faktor (36) eller ved at vi anvender statistiske teknikker for flernivåanalyse $(37,38)$. 


\section{KONKLUSJON}

Tidligere forskning har vist at godt funderte, skolebaserte intervensjoner kan gi en god forebyggende effekt på ungdom i forholdet til røyking $(9,4,1)$. En forutsetning er at de bygger på det vi vet om påvirkning fra sosialpsykologisk forskning. De siste femten årene har man gjennomført programmer med god effekt i andre land, først og fremst USA. Lignende prosjekter har imidlertid også blitt gjennomført uten påviselig effekt, for eksempel i Wales. Derfor er det nødvendig med egne undersøkelser også i Norge.
De kortsiktige resultatene etter det første undervisningsåret i "VÆR røykFRI"-prosjektet er lovende. Gjennom tiltakene har man i noen grad redusert antall elever som begynner å røyke. Gjennom data som samles inn vil vi også kunne se hvilke elevgrupper som er blitt påvirket i størst grad, og eventuelt hvordan og hvorfor nettopp disse er blitt påvirket. Dette vil gi viktig bakgrunnsinformasjon med tanke på å gjøre undervisningsprogrammet så godt som mulig.

\section{REFERANSER}

1. Andersson B, Hibell B. Skoleelevers drogvanor 1993. Resultat från riksundersøkningen i årskurs 6 och 9 . Stockholm: Centralförbundet för alkohol och narkotikaupplysning, 1993.

2. Rimpelä MK, Aarø LE, Rimpelä AH. The effects of tobacco sales promotion on initiation of smoking. Scandinavian Journal of Social Medicine 1993; Supplementum 49.

3. Sosialdepartementet. Sanner T., red. Tobakk og barn. Helsekonsekvenser ved røyking. En rapport fra Sosialministeren. Oslo: Sosial- og helsedepartementet, 1992.

4. Royal College of Physicians. Smoking and the Young. London: Royal College of Physicians, 1992.

5. Sussman S, Dent CW, Burton D, Stacy AW, Flay BR. Developing school-based tobacco use prevention and cessation programs. SAGE publications, California, 1995.

6. Horn D. Modifying smoking habits in high school students. Children 1960; 7: 63-5.

7. Bewley BR, Day I, Ide L. Smoking by children in Great Britain. A review of the literature. London: Social Science Research Council and Medical Research Council, 1976.

8. Nutbeam D, Macaskill P, Smith C, Simpson JM, Catford J. Evaluation of two school smoking education programmes under normal classroom conditions. British Medical Journal 1993; 309: 102-7

9. US Departement of Health and Human Services. Preventing tobacco use among young people. A report of the surgeon general. US Departement of Health and Human Services, Public Health Service, Centers for disease Control and Prevention, National Center for Chronic Disease Prevention and Health Promotion, Office on Smoking and Health, 1994.

10. Bruvold WH. A meta-analysis of adolescent smoking prevention programs. American Journal of Public Health 1993; 83: 872-80.

11. Rooney B. A meta-analysis of smoking-prevention programs after adjustement study design (Dissertation). Minneapolis: University of Minnesota, 1992.

12. Jessor R, Jessor SC. Problem Behavior and Psychological Development: A Longitudinal Study of Youth. New York, NY: Academic Press, 1977.

13. Nutbeam D, Aarø LE. Smoking and pupil attitudes towards school: The implications for health education with young people: Results from the WHO Study of Health Behaviour among Schoolchildren. Health Education Research 1991; 6: 415-21.

14. Aarø LE, Hauknes A, Berglund EL. Smoking among Norwegian schoolchildren 1975-1980: II. The influence of the social environment. Scandinavian Journal of Psychology 1981; 22: 297-309.

15. Ennett ST, Bauman KE. Peer group structure and adolescent cigarette smoking: A social network analysis. Journal of Health and Social Behavior 1993; 34: 226-36.

16. Aarø LE, Bruland E, Hauknes A, Lochsen PM. Smoking among Norwegian schoolchildren 1975-1980: III. The effect of anti-smoking campaigns. Scandinavian Journal of Psychology 1983; 24: 277-83.

17. Defriese G, Crossland C, MacPhail-Wilcox B, Sowers J. Implementing comprehensive school health programs: Prospects for change in American schools. Journal of School Health 1990; 60: 182-7. 
18. Tell GS, Klepp KI, Vellar OD, McAlister AL. Preventing the onset of cigarette smoking in Norwegian adolescents: The Oslo Youth Study. Preventive Medicine 1984; 13: 256-75.

19. Klepp KI, Tell GS, Vellar OD. Ten-Year Follow-up of the Oslo Youth Study Smoking Prevention Program. Preventive Medicine 1993; 22: 453-62.

20. Dusenbury L, Botvin G. Competence Enhancement and the Prevention of Adolescent Problem Behavior. I Hurrelmann K, Løsel F., red. Health Hazards in Adolescence. Berlin: Walter de Gruyter, 1990: 459-78.

21. Botvin GJ, Baker E, Renick NL, Filazzola AD, Botvin EM. A Cognitive-Behavioral Approach to Substance Abuse Prevention. Addictive Behaviors 1984; 9: 137-47.

22. Botvin GJ, Dusenbury L. Substance abuse prevention and the promotion of competence. I Bond LA, Compas BE, red. Primary Prevention and Promotion in the Schools. Newbury Park, Sage, 1989: 146-78.

23. Perry CL, Jessor R. The concept of health promotion and the prevention of adolescent drug abuse. Health Education Quarterly 1985; 12: 169-84.

24. Perry CL, Kelder SH, Murray DM, Klepp KI. Communitywide smoking prevention: Long-term outcomes of the Minnesota Heart Health Program and the class of 1989 study. American Journal of Public Health 1992; 82: 1210-6.

25. Rotter JB. Social learning and clinical psychology. Englewood Cliffs, New Jersey: Prentice Hall, 1954.

26. Rotter JB. Generalized expectancies of internal versus external control of reinforcement. Psychological Monographs 1966; 80: 1-28.

27. Wallston BS, Wallston KA. Locus of control and health. A review of the litterature. Health Education Monographs 1978; 6: 107-17.

28. Ottawa Charter for Health Promotion. WHO, Ottawa, Canada, 1986.

29. Brehm J. A theory of psychological reactance. New York: Academic Press, 1966.

30. Bandura A. Social learning theory. Englewood Cliffs, New Jersey: Prentice-Hall 1977.

31. Perry CL, Baranowski T, Parcel GS. How individuals, environments, and health behavior interact: social learning theory. In K Glanz, FM Lewis, BK Rimer (eds.). Health behavior and health education. Theory, research, and practice. San Francisco: Jossey-Bass Publishers 1990: 161-86.

32. Janis IL, King BT. The influence of role-playing on opinion change. Journal of Abnormal and Social Psychology, 49: 211-8.

33. Eagly AH, Chaiken S. The psychology of attitudes. Fort Worth: Harcourt Brace Jovanovich 1993.

34. Fergusson DM, Horwood LJ. Transitions to cigarette smoking during adolescense. Addictive Behaviors 1995; 20: 627-642.

35. Rogers E. Diffusion of innovations (Fourth edition). New York: The Free Press, 1995.

36. Wold B, Aarø LE, Smith C. Health Behaviour in School-Aged Children. A WHO cross-national survey (HBSC). Bergen: Universitetet i Bergen, HEMIL-senteret (HEMIL-rapport nr 94-4).

37. Ringdal K. Methods for multilevel analysis. Acta Sociologica 1992; 35: 235-43.

38. Paterson L, Goldstein H. New statistical methods for analysing social structures: an introduction to multilevel methods. British Educational Research Journal 1991; 17: 387-93. 